\title{
ポルトガルの地理学
}

池俊 介*

\section{Geography in Portugal}

Shunsuke IKE*

\begin{abstract}
Until the 1970s the French school of geography exerted a tremendous influence on Portuguese geographers, many of whom made major contributions to studies on the relationship between nature and human beings. Since the Carnation Revolution in 1974, however, various strands of geographical thought have been introduced to the discipline of geography in Portugal, due to increasing academic exchanges with foreign scholars, which have led to a gradual diversification of themes in studies of geography. For instance, research on regional planning and urban planning has progressed since the 1980s, making applied geography one of the mainstreams of geographical studies in Portugal. Recently, research institutions in the major universities of Portugal have also been reorganized, obtaining corporate status to receive more research funds. They are expected to produce excellent research outputs soon after their establishment.
\end{abstract}

Key words : Portugal, history of geography, applied geography, internationalization, research institutions

キーワード : ポルトガル, 地理学の歴史, 応用地理学, 国際化, 研究組織

\section{I. はじめに}

ヨーロッパの南西端に位置するポルトガルで は, 1936 年から約 40 年間いわゆるサラザール 独裁体制が続き，アフリカのアンゴラ・モザン ビーク等の植民地の維持に最後まで固執して他国 から「最後の植民地帝国」と挪揄された。しか し，1974 年の無血革命によるサラザール体制の 崩壊に伴い民主化が急速に進み, 大学における地 理学の研究・教育体制も大きな変革を遂げた。さ らに, 1986 年の $\mathrm{EC}$ 加盟以後は, 今日の $\mathrm{EU}$ 諸 国との幅広い研究交流がより活発化し, フランス 地理学派の特徵を残しつつも, 研究分野の多様化 が進んだ。
そこで本稿では，この約 50 年間に急速な変化 を遂げてきたポルトガルの地理学の歩みを概観す るとともに，全国的に組織された学会の活動状 況, 地理学の研究・教育において中心的な役割を 担ってきたリスボン大学・コインブラ大学におけ る研究・教育体制の近年の変化と現状について整 理・検討することにする。

\section{II. 地理学教室の成立と発展}

ポルトガルの高等教育機関における近代地理学 の教育は，国内最古の歴史を誇るコインブラ大学 に「地理学概論」の科目が 1830 年に設置された ことによりはじまり，1911年にはリスボン大学 の「語学・文学」領域のなかに地理学者の養成の

* 早稲田大学教育・総合科学学術院

* Faculty of Education, Waseda University, Tokyo, 169-8050, Japan 
ための「歴史学・地理学課程」がはじめて置かれ た。さらに, 1930 年の大学改革により歴史学課 程が設置されたのに伴い，それまで「歴史学・地 理学課程」の枠組みにあった地理学も独自の 4 年間の課程をもつことになった。地理学課程で は, まず $1 \cdot 2$ 学年で理学部の数学, 物理学, 数 理地理学, 自然地理学等の科目を学んだ後, 3 ・ 4 学年で文学部の地理学史, 人文地理学, ポルト ガル植民地の地理学, 政治・経済地理学, ポルト ガル史，植民地化の歴史などの科目を学ぶ体制が とられ，歴史学との強い結び付きは維持された が, 従来に比べ全体として自然科学への傾斜が強 まった（Gaspar e Gama, 1980）。

また，1943 年にはリスボン大学文学部に Centro de Estudos Geográficos (地理学研究セン ター：以下 CEG と表記）が設立されたが， CEG はポルトガルにおける地理学研究の拠点として, その後の地理学界をリードすることになる「リス ボン学派」の形成とその発展に大きく貢献するこ とになった。ちなみに, コインブラ大学でも 1949 年に CEG が設立された。

リスボン大学では, その後, 1957 年に地理学 講座の再編が行われ, 自然地理学・人文地理学・ 地誌学に明確に区分された 22 の授業科目と演習 から構成される新たなカリキュラムが誕生すると ともに, 修学期間も 4 年から 5 年に延長された。 新カリキュラムでは理学部の地質学, 鉱物学の授 業の履修などを通じて自然科学との繋がりは維持 されたが, 週 4 時間の「人文地理学」 $(2 \cdot 3$ 学 年）が設置されたほか，新設の「民族学」をはじ めとする文学部の科目を幅広く履修できるように 構成され, 人文科学への傾斜が再び顕著となっ た。そして, この再編により, 地理学はリスボン 大学文学部において確固たる地位を築くことに なった（Gaspar e Gama, 1980）。

リスボン大学の地理学講座は多くの優秀な地理 学者を輩出してきたが，そのなかの一人に CEG の設立に尽力した著名な地理学者 O. Ribeiro （1911-1997）がいた。O. Ribeiroは，当時の多 くのポルトガル人研究者がそうであったように 1937 ～ 40 年にパリ大学（ソルボンヌ）に留学
し, E. de Martonne, A. Demangeon らの薰陶 を受けたほか, P. Vidal de La Blache の著作を通 じてフランス地理学派の影響を強く受けた（Ribeiro, 2003)。彼の業績は地質学, 気候学から人 類学，歴史学の分野に至るまできわめて多岐にわ たったが，当然ながら主要な関心は人間と環境と の関係の考察に重点を置いた地誌学的研究にあっ た。

O. Ribeiroの 300 を超す膨大な業績のなかで も Ribeiro（1945), Ribeiro（1961）は代表作と して知られ，とくに前者はポルトガル地誌に関す る古典的名著として現在も版を重ねている。ま た，CEGで長年教鞭をとったフランス出身の S. Daveau（1925-)，ポルトガルを中心としたイべ リア半島の研究で有名なドイツ人地理学者の $\mathrm{H}$. Lautensach との共著である『Geografia de Portugal 全 4 巻』（Ribeiro et al., 1987-1991）は, ポルトガル地誌研究の集大成とも言える労作であ る。

また，O. Ribeiro とほぼ同時代にコインブラ大 学の地理学研究を指導したA. Girão (1895-1960) と F. Martins（1916-1982）も，それぞれ人文地 理学, 自然地理学の研究に中心を置きつつも, 人 文・自然科学の両面にわたる幅広い地理的事象 に関心をもち，とくに F. Martins は P. Vidal de La Blache の著作『Principes de géographie humaine (人文地理学原理)』を翻訳するなど人文 地理学の発展に貢献する業績も残した。これは, リスボン大学でおもに自然地理学の講義を担当し た S. Daveauにも共通した特徴であり，フラン ス地理学派の強い影響のもとで多くの地理学者が 地誌学を中心とした人文・自然地理学にわたる広 範な分野の研究に従事した。

一方，1974 年の革命を機に植民地を解放する までは，ポルトガルはアフリカを中心に植民地を 維持し, 本国と植民地の結び付きを強化した大西 洋経済圈の構築を図ろうとした。そのため, 大学 においても植民地経営に寄与する分野が重視され る傾向にあった。例えば, リスボン大学では 1957 年のカリキュラム再編後も, 従来の科目 「植民地の地理学」が「熱帯地域の地理学」と名 
称を変えて残存した（Gaspar e Gama, 1980）。 また, 地質学, 人類学, 民俗学も同様に重視さ れ, 植民地経営と密接に関連した熱帯地域研究は 1975 年に大半の植民地を解放した後も引き続き 維持された。例えば，1976 年に CEGの組織が 再編されたが, 再編後の 6 つの研究グループは 「自然地理学」(代表：S. Daveau),「熱带地域の 地理学」(代表 : I. Amaral), 「大西洋の島嶼地理 学」(代表: O. Ribeiro), 「人文地理学・地誌学」 (代表 : C. Medeiros),「文化人類学」(代表 : M. Guerreiro),「地域計画・都市計画」(代表：J. Gaspar）から構成され, 植民地経営の時代の特 徵を色濃く残していた。当該分野の抵抗を押し切 る形でようやく再編・縮小（脱熱帯化）が実現し たのは 1990 年代のはじめのことであった（Bandeira, 2011)。

実際の地理学研究においても, 1980 年代まで 旧植民地を中心とするアフリカ・南米に関する研 究が盛んで, アフリカ西部とブラジルの半乾燥地 域の地形に関する Daveau（1967），モザンビー クの主要な港湾都市ベイラの都市構造をテーマと したAmaral（1978），モザンビーク南部の石灰 岩質の海食崖・波食棚の分布パターンについて明 らかにした Moreira（1983）をはじめ, 熱帯地 域を中心に多くの研究が蓄積された。これらの研 究成果は，ポルトガル語を公用語とするパート ナーとして旧植民地諸国との協力関係が深まりつ つある近年, その価值が再評価されつつある。

\section{1974 年革命以後の変化}

\section{1）研究の多様化}

1974 年 4 月 25 日に起こった無血革命は, 社 会主義や労働組合運動の弾圧, 植民地の維持（植 民地戦争の継続）などに特徵づけられるサラザー ル体制を崩壊させ，その後，政治・社会的な民主 化が急速に進められた。民主化の波は大学の研 究・教育体制にも及び, 革命後から 1977 年にか けてリスボン大学やコインブラ大学で教員・学生 による自主的なカリキュラム再編が行われ，とく にリスボン大学では研究・教育の一貫性を重視し たカリキュラムの構成について熱心な議論が繰り
返された。その結果, 教員・学生・職員から構成 される「全体会議」が, 地理学教室の研究・教育 のあり方や運営に関する重要問題を最終的に議決 する組織として設立された。また，助手を含む全 教員と各ゼミから選出された学生代表で構成され る「教育審査委員会」も組織され，そこでの議論 を踏まえて授業科目（演習を除く）の半期化，第 1 学年における統合科目としての「地理学入門」 の新設，授業時間数の $25 \%$ 増加などが実現され たほか，試験における最低基準の設置なども検討 された（Gaspar e Medeiros, 1980）。ただ，実際 にはこれらの改革に無関心な教員も多く, 教育省 (当時) 主導による 1978 年のリスボン大学文学 部の学部改革のなかで, 地理学教室の自主的な改 革の成果は否定され活動に事実上の終止符が打た れた。しかし, 改革の議論のなかで教員相互の理 解が深まったほか, 学生の学習・研究に対する意 欲が向上し, 一連のカリキュラム改革は地理学の 研究・教育を質量ともに大きく前進させた（Gaspar e Medeiros, 1980)。

世界的にみて, 1960 年代末から地理学研究に 専門分化の兆しが見られはじめたが，当時のポル トガル地理学界では依然としてフランス地理学派 の影響力が強く，また地理学者の養成機関も実質 的にリスボン・コインブラの 2 大学に限られ, スクールの多様性が欠如していたため，ポルトガ ルでは新たな方法論の導入に対する関心が一般に 低かった。しかし, 革命後の地理学教室のカリ キュラム改革の自由な雲囲気のなかで, P. Gould, P. Haggett, T. Hägerstrand, K. Cox, B. Berry, W. Garrison などアングロサクソン系の地理 学者による研究への関心も高まっていった。 (Gaspar e Gama, 1980)。とくに, $1966 \sim 68$ 年にスウェーデンのルンド大学に留学しヘーゲル ストランドの直接の指導を受けたJ. Gaspar （1942-）のグループを中心に，彼自身の博士論 文 Gaspar（1972）で示されたような，立地論や 行動地理学に影響を受けた研究も次第に進められ るようになり，これらの成果は 1966 年から刊行 (年 2 回) がはじまった CEG の学術雑誌『Finisterra』に揭載された。 
表 1 『Finisterra』誌における掲載論文（論説）の分野別一覧.

Table 1 Number of articles according to the research area in "Finisterra".

\begin{tabular}{|c|c|c|c|c|c|c|c|c|c|c|c|}
\hline 年 & $1966-70$ & $71-75$ & $76-80$ & $81-85$ & $86-90$ & 91-95 & $96-2000$ & $01-05$ & $06-10$ & 計 & $\%$ \\
\hline 地理学方法論 & 4 & 1 & 1 & 2 & 0 & 0 & 0 & 1 & 0 & 9 & 3 \\
\hline 地 誌 & 5 & 1 & 1 & 1 & 1 & 0 & 0 & 0 & 0 & 9 & 3 \\
\hline 地図・リモートセンシング・GIS & 0 & 0 & 1 & 2 & 2 & 2 & 2 & 13 & 2 & 24 & 7 \\
\hline 地域計画・地域開発 & 0 & 0 & 0 & 1 & 1 & 3 & 0 & 1 & 1 & 7 & 2 \\
\hline 気 候 学 & 0 & 2 & 2 & 6 & 6 & 2 & 7 & 0 & 4 & 29 & 9 \\
\hline 地 形 学 & 7 & 6 & 7 & 6 & 3 & 4 & 4 & 1 & 4 & 42 & 12 \\
\hline その他の自然地理学 & 2 & 2 & 1 & 0 & 0 & 9 & 5 & 3 & 4 & 26 & 8 \\
\hline 農村地理学 & 6 & 2 & 2 & 2 & 2 & 1 & 0 & 0 & 1 & 16 & 5 \\
\hline 都市地理学 & 10 & 5 & 5 & 2 & 0 & 4 & 4 & 5 & 15 & 50 & 15 \\
\hline その他の人文地理学 & 4 & 5 & 4 & 8 & 15 & 9 & 7 & 10 & 14 & 76 & 22 \\
\hline その他 & 3 & 7 & 5 & 4 & 3 & 1 & 1 & 19 & 4 & 47 & 14 \\
\hline 合 計 & 41 & 31 & 29 & 34 & 33 & 35 & 30 & 53 & 49 & 335 & 100 \\
\hline
\end{tabular}

『Finisterra』各号より作成.

表 1 は, ポルトガルの地理学研究の動向を知 る手がかりとして, 地理学界で最も権威のある学 術雑誌である『Finisterra』に掲載された論説に ついて，テーマ別に分類したものである1)。当初 は本数が多かった「地誌」に関する論説は 1980 年代までに姿を消し，また「農村地理学」の論説 が減少傾向をたどったのに対し，「都市地理学」 は一定の水準を維持しているのが目立つ。90号 （2010 年）にはバルセロナに関する特集号が組ま れたことから，とくに掲載本数が多くなってい る。また，1980 年代から「その他の人文地理学」 に分類される論説が増加し, 研究分野がかなり多 様化したことがわかる。その内容は多岐にわたる が，42 号の「工業化」(1986 年)，57号の「産 業構造の変化（第三次産業化）」(1994 年), 77 号の「移民」(2004 年), 88 号の「イノベーショ ン」(2009 年) などの特集号が組まれ，これらの 年にはとくに掲載本数が増加している。また, 「地図・リモートセンシング・GIS」では, 1970 年代後半から地図学に関する論説が定期的に掲載 されたほか ${ }^{2}, 75 \cdot 76$ 号（2003 年）には GIS に関する論説が集中的に掲載された。なお， 72 号（2001 年）には「景観」に関する特集が組ま れたため「その他」の本数が極端に多くなってい
る。このように, 1980 年代以降, 森林火災, 工業 化，移民，イノベーションなどポルトガルの抱え る重要課題が特集テーマとしてとりあげられる一 方，従来の区分には収まらないスポーツ（Gaspar et al., 1982），自殺（Freitas, 1982），犯罪（Fonseca, 1984), ジェンダー（André, 1990）など新 しいテーマに挑戦した論説が掲載されるようにな り, 研究の多様化と専門分化が著しく進んだ。

一方， 1970 年代後半以降に加速した大学教育 の大衆化に伴い, リスボン大学地理学教室の入学 者数は 1973 年から 1979 年までの間に約 200 人 から約 400 人へと倍増した (Gaspar e Medeiros, 1980)。その結果, 従来の地理学教室の卒業生の おもな就職先であった基礎教育第 3 期 (中学校) ・ 中等教育 (高校) の教員以外の就職先を開拓する 必要に迫られた。そこで注目されたのが地域計 画・都市計画の分野への進出であり, 実際に国・ 市町村の地域計画担当者として就職する学生も増 加した。そのため，地域計画の実務能力を高める ための理論やスキルに関する授業科目の設置が各 大学で積極的に進められた。また，1980年にリ スボン新大学の「地理学・地域計画コース」が, 1983 年にはアヴェイロ大学の「地域計画・都市 計画コース」が新設されるなど，応用地理学は 


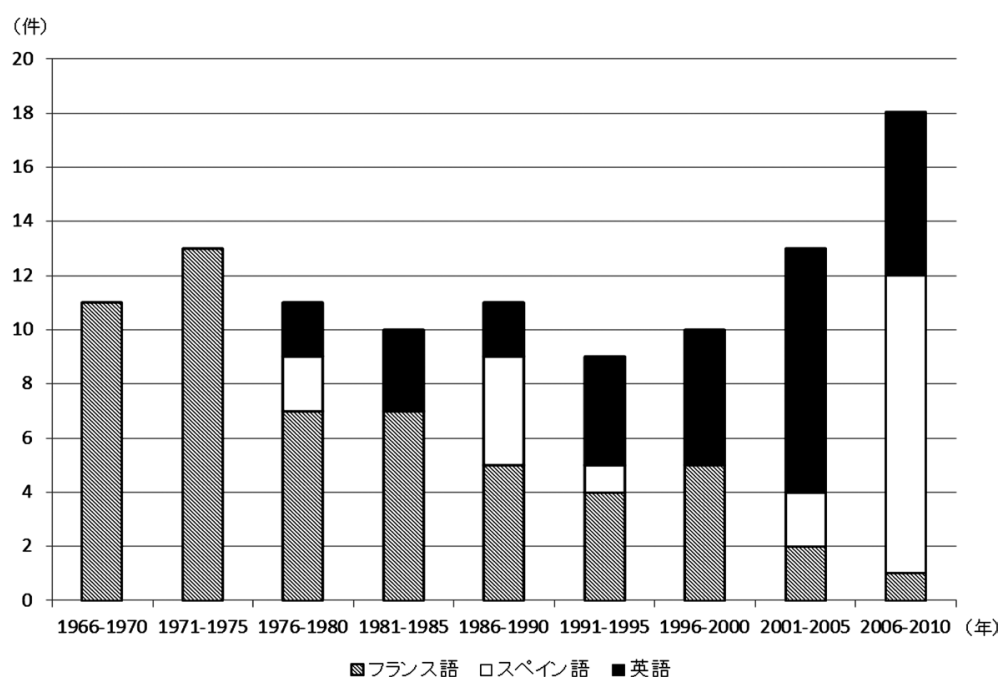

『Finisterra』各号より作成.

図 1 『Finisterra』誌における外国語論文（論説）の掲載状況.

Fig. 1 Number of articles written by foreign languages in "Finisterra".

1980 年代の地理学界の大きな流れを形成した。 現在もリスボン大学をはじめとして地域計画・都 市計画等の応用地理学に関する授業が学士課程 $(3$ 年 $)$ ・修士課程 $(2$ 年) のカリキュラムのなか で重視されており ${ }^{3)}$, ポルトガル地理学の大きな 特徵の 1 つとなっている。

\section{2）国際化の進展}

フランス地理学の影響が強かったポルトガルで は，すでに 1960 年代からフランス出身の S. Daveau が CEG の専任教員として教鞭をとるほか, フランス人の研究者の招へいや論文執筆依頼など の形で外国との学術交流は早くから行われていた が，広く国際的な学術交流が本格化したのは 1970 年代末からであった。とくに 1986 年の EC 加盟後は，政治・経済分野のみならず学術交流の 面でも EU 諸国との関係が深まった。

隣国スペインとの交流では, 1979 年に最初の イベリア地理学会議 (Colóquio Ibérico de Geografia）がサラマンカで開催されて以来, 2010 年のポルトでの開催で 12 回目を迎えている。図 1 は, 『Finisterra』に掲載された外国語の論説の 掲載状況を示したものであるが，イベリア地理学 会議の開催を機にスペイン語論文の掲載がはじま
り，その後，本数が増加していることがわかる。 言語的な障壁が低いこともあり，スペインとの交 流は比較的活発であり，90 号（2010 年）のバル セロナ特集では 9 本の論説のうち 8 本の執筆を スペイン人地理学者が担当した。

国際的な学術交流において画期となったのは, 1998 年にリスボンで開催された IGU（国際地理 学会議）の地域会議（Regional Conference）で あった。「大西洋：過去・現在・未来」という 「大西洋国家ポルトガル」としての歴史を反映し たテーマで行われたこの国際会議は，研究者の国 内および海外との交流ネットワークの拡大に寄与 したほか, 研究の国際化への対応の必要性をポル トガル人地理学者に痛感させ, 国際的な学術交流 が活発化してゆく重要な契機となった（Bandeira， 2011) ${ }^{4)}$ 。

こうした研究の国際的な交流が進むなかで, 『Finisterra』にも 1970 年代末から英語論文が掲 載されるようになり，イギリス人地理学者の投稿 やポルトガル人地理学者による英語論文の投稿が 増加した。その一方で, かつては学術言語として 卓越した立場にあったフランス語は，とくに今世 紀に入ってから使用される頻度が減り，その地位 
を完全に英語に奪われる形となっている。

\section{IV. 学会活動と大学の研究・教育体制の現状}

\section{1）学会活動の概要}

ポルトガルには 3 つ全国的な学会が存在す るが，そのなかで最も長い歴史をもつのがリスボ ン地理学協会 (Sociedade de Geografia de Lisboa）である。1875 年に創設されたリスボン地 理学協会は，イギリスをはじめとするヨーロッパ 諸国でも同様の動きがあったように，探検や植民 地経営のための研究を支援する目的で設立された ものであり，おもな関心はポルトガルの植民地が 存在するアフリカにあった。当初から政治家や ジャーナリストたちの社交の場としての色彩が強 かったが, 現在ではアカデミックな地理学研究と はほとんど無縁な存在となっており，協会のアフ リカ関係の所蔵品の展示, 講演, 図書館の一般開 放などの文化事業を行っているにすぎない。学会 誌として 1986 年創刊の『Boletim da Sociedade de Geografia de Lisboa』（年 1 回）があるが, 最新の地理学研究の成果が掲載されることは皆無 に近い。

今世紀に入ってから，ポルト大学，リスボン新 大学, エヴォラ大学, ギマランイスのミーニョ大 学に地理学の博士課程が設置されたが，それまで は国内で地理学者を輩出しうる大学は実質的にリ スボン・コインブラの 2 大学に限られていた。 そのため, 全国的な学会組織への関心は低かった が，国際的な学術交流が活発化するなか，ようや く 1987 年に地理学界の中心的な学会としてポ ルトガル地理学会 (Associação Portuguesa de Geógrafos）が設立された。ポルトガル地理学会 の会員数は 900 人以上にのぼり, 大学・研究機 関の地理学研究者のみならず, 中等教育・基礎教 育の教員，国・地方の公的機関や民間のシンク夕 ンク等に勤務する地域計画・都市計画の実務担当 者などが多数所属している。

ポルトガル地理学会では, 3 年に 1 回のペース で大会を開催しており, 最近では 2011 年 10 月 に「新たな挑戦のための地理学再考」というテー マでリスボンにおいて開催された。また， 3 年に
1 回開催されるイベリア地理学会議も, 現在は本 学会とスペイン地理学会の共催となっている。会 員がアカデミックな地理学研究者に限られないた め，教員や実務家のニーズにも応える必要性が高 く，例えば 2011 年のリスボン大会では 13 の分 科会のうち 1 つが地理教育, 4 つが地域計画・地 域整備等に関するものとなっている。なお，学会 誌としては 1990 年に『Inforgeo』が創刊され, $1 \sim 2$ 年に 1 回のペースで現在も刊行が続けられ ている。

一方, 1987 年に地理教育学会 (Associação de Professores de Geografia) が，ポルトガル地理 学会の設立直後に発足した。この学会は, おもに 中等教育・基礎教育の教員から構成され，地理教 育に関する各種の講座の主催, 大学主催の講習会 情報の提供，スペインとの地理教育に関する会議 の共催など，地理教員の授業づくりに寄与する情 報を提供してきた。学会誌としては 1988 年に創 刊された『Apogeo』があり，年 $1 \sim 2$ 回のペー スで刊行されている。

地理教育学会とポルトガル地理学会は, 当初は 競合関係にあったが，地理教育学会は地理教育の 指導法の普及，中等教育・基礎教育の教育課程に おける地理関係科目の維持のための活動, 教員組 合の利益擁護のための活動などに特化する一方, ポルトガル地理学会は地理学プロパーの研究, 地 域計画等の分野への地理出身者の進出を促進する ための活動に特化するようになり，近年は両学会 の協働が進みつつある（Bandeira, 2011）。

\section{2) 大学の研究・教育体制とその再編}

国内で最大の規模の地理学研究組織は, 約 150 名の研究員を擁するリスボン大学の CEGである。 研究員のうち, 助手以上の主要スタッフは 42 名 にのぼり ${ }^{5)}$, 正教授 (Professor Catedrático) 6 名, 準教授 (Professor Associado) 11 名, 助教授 (Professor Auxiliar) 24 名, 助手 (Assistente) 1 名から構成される。これらのスタッフの専門分野 の内訳は, 自然地理学 15 名（うち地形学 7 名, 気候学 5 名), 人文地理学 23 名, 地図学・地理 教育等 4 名と，文学部に長く基礎を置いてきた 組織にしては自然地理学のスタッフも充実してい 
る。人文地理学のスタッフの専門分野は多岐にわ たるが，ポルトガルの地理学界では地域計画・都 市計画等の実学的な側面が重視されてきたため, 狭義の専門分野とは別に地域計画を研究の柱の 1 つに掲げる地理学者が目立つ。また，CEGには 「南極の環境と気候変化（代表：G. Vieira）」「気 候変化と環境（代表 : M. Alcoforado）」「地理学. 地図学の歴史と教育（代表：H. Cachinho）」「移 民・空間・社会（代表：M. Fonseca）」「モデル 化・地域計画（代表：M. Costa）」「地域戦略・ 地域政策（代表：I. André）」「都市研究（代表 : J. Malheiros)」「環境ハザードのリスク評価・管 理（代表：J. Zêzere）」「海岸・河川システム： ダイナミクス・環境変化・地域管理（代表：A. Pereira)」「観光・文化・地域（代表 : J. Simões）」 の合計 10 の研究グループが組織されており，国 内外の研究機関との共同研究も積極的に進められ ている。なお，これらの研究成果は，報告書・専 門書として CEG から年に 5 〜 10 冊のペースで 刊行されており，CEGの発足以来，刊行された 書籍はこれまで約 340 冊にのぼっている。

リスボン大学における地理学教育を長期間にわ たり担ってきたのは文学部地理学教室（Departamento de Geografia) であったが，2009 年に地 理学の教育部門は文学部から分離され，学部と同 レベルの学内組織として新設された「Instituto de Geografia e Ordenamento do Território」(地 理学・地域管理研究院：以下 IGOT と表記）の もとに研究組織である CEG とともに置かれるこ とになった。かつての地理学教室は所属する文学 部からの自立性がそしく法人格をもたなかったた め, 地理学研究者は各種プロジェクトの申請に学 部の認可を必要とするなど, 学外の研究組織との 共同研究等に以前から支障をきたしていた。ま た，CEGは多くの研究員を抱えていたが，別組 織である地理学教室で教鞭をとるのはその一部に すぎず，CEGの人材を学生の教育に十分に活用 することができなかった。そのため，リスボン大 学の地理学研究者たちは教育と研究の機能を統合 し，CEGの人的資源を教育に活かすことが可能 な新たな組織の設立を模索していたが，2007 年
からはじまったリスボン大学の組織改革の波に便 乗して，2009 年に法人格をもつ独立した組織で あるIGOTの設立に成功した。これにより，教 育・研究の一体性が強化されるとともに, 各種の ファンドの受け入れや，国内外の他の研究機関と の共同研究をより円滑に実施することが可能と なった ${ }^{6)}$ 。

一方，コインブラ大学でも 1949 年にリスボン 大学に続いて CEG が設立され，1974～93 年の 活動休止期間を除き，コインブラ大学の地理学研 究組織の中核として機能してきた。現在のスタッ フは 25 名（正教授 4 名, 準教授 5 名, 助教授 6 名, 助手 10 名）で，専門分野は自然地理学が 12 名, 人文地理学が 12 名, その他 1 名と, リスボ ン大学と同様, 自然地理学のスタッフも充実して いる。ただ，リスボン大学の CEGに比べて研究 組織としての規模は小さく劣勢が否めないため, 2008 年にポルト大学（地理学スタッフ 26 名）・ ミーニョ大学（同 12 名）と合同の研究組織であ る Centro de Estudos em Geografia e Ordenamento do Território（地理学・地域管理研究 センター：以下 CEGOT と表記）が設立された。 CEGOT の新設は，研究組織の充実により教育科 学省の科学技術基金からより多くの研究費を獲得 し，リスボン大学に対抗しうる研究体制の構築を めざしたもので，大学の枠組みを越えた画期的な 試みとして注目を集めている。CEGOT では，3 大学の地理学研究者が「自然と環境のダイナミズ 么（代表：N. Cunha）」「都市・競合・充足（代 表：J. Fernandes）」「文化景観・観光・発展（代 表 : F. Cravidão)」の 3 領域に分かれて研究を進 めつつあり，その成果が期待されている。

なお，コインブラ大学では教育体制の再編も同 時に実施され, 文学部内の組織として地理学研究 院 (Instituto de Estudos Geográficos : 以下 IEG と表記）が組織された。この再編により研究組織 である CEGも IEGの傘下に置かれ，リスボン 大学の IGOT と同様に研究と教育との関係強化 が目指されている。なお, リスボン大学の刊行す る『Finisterra』とならぶポルトガルを代表する 学術雑誌である『Cadernos de Geografia』(1986 
年〜）も，かつてはコインブラ大学の地理学教室 から刊行されていたが，現在は IEG が刊行して いる。

\section{3) 深刻化する就職問題}

大学における教育制度の再編が進む一方, 地理 学を学んだ学生の就職問題が大きな課題となって いる。ポルトガルでは，1979 年に各種の専門学 校を再編してポリテクニコ（実務系大学）が全国 的に創設されるとともに，1986 年に私立大学の 設立が認可されるようになった。その結果， 1980 年代に地理学研究者のポストが増加したも のの, 大学教育の大衆化によって大幅に学生数が 増加したため, 卒業生が研究職に就ける確率がき わめて低い状況になった。とくに各大学で博士課 程の新設が進められた 2000 年以降は，国内での 就職が困難なため海外の研究機関に職を求める学 生が増えており，ポルトガルを公用語とする旧植 民地諸国（アンゴラ・モザンビーク・サントメ = プリンシペ・ギニアビサウ・東チモール）の大 学・研究機関に就職する事例も多くなっている。

また，かつては学部卒業生の就職先として基礎 教育・中等教育の教員の重要性が高かったが，リ スボン・コインブラ大学のほか, ポルト大学 (1972 年), リスボン新大学（1980 年)，アヴェ イロ大学 (1983 年), ミーニョ大学 (1995 年), 私立のルゾフォナ大学 (2000 年), エヴォラ大学 （2003 年）など次々に地理学のコースが新設さ れ，学部の卒業生数が教員の需要を大きく上回る 状況となった。そのため, 基礎教育・中等教育の 教員需要も飽和状態にあり, 教職への道は厳しさ を増している7)。また，地域計画・都市計画に関 する授業を通じて専門的な知識・技能を習得し, かつては国の官庁のほか, 市町村の役場や地域計 画・開発委員会，あるいは民間のシンクタンク等 に地域計画・都市計画の担当者として就職する事 例も多かったが，それらの担当者のポストもすで に多くが充足されており，とくに2004 年頃から は景気が低迷するなか新卒者の就職は困難を極め ている。このような状況のなかで，地理学を学ほ うとする現役の受験生が減少する一方，キャリア アップを目指した社会人の入学者が増加してい
る。その結果，各大学の地理学のコースでは相対 的に社会人学生の割合が増加する傾向にある。例 えばIGOT の場合, 学部学生の約半数が社会人 で占められるに至っている8)。

\section{V.おわりに}

ポルトガルでは，かつてはフランス地理学派の 影響が強く，自然環境と人間との関係の考察を中 心とした地誌学研究が主流を占めたが，1980 年 代から国際的な学術交流が活発化するなか，アン グロサクソン系の地理学者の影響も強まり研究分 野の多様化が進んだ。同時に，地域計画・都市計 画等の応用地理学の分野への関心が高まり，地理 学を学んだ学生の多くがこれらの実務的な分野へ 進出した。しかし，地域計画・都市計画の分野で 地理学者が必ずしも中心的な役割を果たしてきた とはいえず，都市工学，建築学などの他分野に比 べて「半周辺的」な位置にあるとの指摘もある (Bandeira, 2011)。また，EU 諸国を中心に学術 的な交流が進みつつあるが，残念ながらポルトガ ルの地理学者による研究が他国に強い影響力を与 えるまでには至っていないのが現状である。

一方，近年は大学における地理学の研究・教育 体制の再編が活発化しており，研究と教育との関 係強化が図られている。しかし，従来の学部卒業 生の主要な就職先であった基礎教育・中等教育の 教員, 地域計画・都市計画の担当者の需要の減少 により，学部新卒者の就職をめぐる環境は厳しさ を増している。このような状況のなかで，現役受 験生が減少する一方，キャリアアップを目指す社 会人の入学者が増えており, 結果として在籍学生 に占める社会人学生の割合が高くなっている。

大航海時代に世界に雄飛したポルトガルは，そ の後の歴史的展開のなかで次第に国力が低下し, ヨーロッパの「周辺国」としての地位を甘受せざ るを得なくなった。研究資金の多臭が大きく研究 成果を左右しつつある今日，国家財政の赤字に悩 むポルトガルの地理学者の置かれた状沉は厳し い。しかし，近年は研究組織の再編・強化を図る ことにより，ヨーロッパの地理学界のなかでの存 在感を増し「脱周辺化」するための懸命な取り組 
みが進められている。こうした新たな動きが奏功 し，ポルトガルの地理学界から優れた研究成果が 早期に生み出されることが期待されている。

\section{謝 辞}

本稿の執筆に当たり, リスボン大学 (Universidade de Lisboa）の Luís Moreno 助教授に資料の提供等の便 宜を眓っていただいた。記してお礼申し上げる。

\section{注}

1）リスボン大学で正教授を務めた地理学者の退職時 には記念号が刊行される慣行があるが，記念号に掲 載された論文については退職者の専門分野に関する ものが必然的に多くなるため除外した。また，65号 （1998 年）の IGU 特集号も外国人の執筆者が大半を 占めるため除外した。なお，各号には論説以外にも 研究ノートやその他の記事が掲載されているが, 研 究ノートは時期により質・量の差異が大きいため, ここでは論説のみを整理の対象とした。

2）ポルトガルに扔ける地図学研究の成果をまとめた 代表的な著作として，Dias（1995）などがある。

3）例えば, リスボン大学の学士課程には「地域計画 入門」「都市政策」「環境と地域管理」など，地域計 画・都市計画に関する授業科目が現在も多く設置さ れている。なお，1999 年のボローニャ宣言に基づき， ヨーロッパ各国では高等教育の質保証を目的とした ボローニャプロセスと呼ばれる改革が進められてい るが，ポルトガルでも単位制度の導入や学位制度の 整備などの制度改革が行われ，大学教育は学士課程 (3 年), 修士課程 ( 2 年), 博士課程（5 年）に明確 に区分された。

4）地域会議の開催にあわせて『Finisterra』の IGU 特集号 (65 号) が刊行され，世界の 19 人の地理学 者から論考が寄せられたが，日本人では竹内啓一と 野澤秀樹の論文が揭載されている。

5)これ以外に，現役を引退したS. Daveauも名簿上 は正教授として名を連ねており，形式上は 43 名のス タッフから構成される。

6）研究期間は多様であるが，1〜3年のプロジェク トが多い。IGOTでは年間扔よそ 50 件のプロジェク 卜が行われて扔り，外部資金を得て実施されるプロ ジェクトは, 学生の授業料とともに IGOT の重要な 財源となっている。

7）現在，中等教育扔よび基礎教育第 3 期の教員免許 を取得するためには, 学士課程（3 年）に加えて, 修士課程（2 年）を修了することが義務づけられて いる。そのため, 学生にとって教職へのハードルは 以前にも増して高くなっている。

8） 2011 年の IGOT 入学者の年齢構成は, 20 歳以下 が $42 \%, 20$ ～ 23 歳が $33 \%, 23$ 歳以上が $25 \%$ であ り，平均年齢は 23.3 歳となっている。

\section{文献}

Amaral, I. (1978): Contribuição para o conhecimento do fenómeno de urbanização em Angola. Finisterra, 25, 43-76.

André, I. (1990): O género em geografia: Introdução de um novo tema. Finisterra, 50, 331-348.

Bandeira, M. (2011): A geografia portuguesa do tempo democrático. Esbaço histórico-síntese dos últimos 35anos da geografia e dos geógrafos em Portugal. Actas do XII Colóquio Ibérico de Geografia, Porto, 6 a 9 de Outubro 2010. [no prelo]

Daveau, S. (1967): Problèmes morphologiques comparés des régions semi-arides en Afrique Occidentale et au Brésil. Finisterra, 2, 153-173.

Dias, M. (1995): Os mapas em Portugal. Da tradição aos novos rumos da cartografia. Edições cosmos.

Fonseca, M. (1984): Notas para uma geografia do crime em Portugal: 1950-1981. Finisterra, 38, 171204.

Freitas, E. (1982): O suicidio em Portugal no séc. XX: elementos piricos para a pesquisa. Finisterra, 34, 267-300.

Gaspar, J. (1972): A Área de Influência de Évora: sistema de funções e lugares centrais. Dissertação de doutoramento, Universidade de Lisboa.

Gaspar, J. e Gama, A. (1980): Perspectivas da geografia em Portugal: ensino, investigação e carreiras. in Quatro ensaios sobre a geografia em Portugal edited by Arroz, E., Ferrão, E., Gama, A., Gaspar, J., Medeiros, A. e Reis, D., Centro de estudos geográficos, Universidade de Lisboa, 1-14.

Gaspar, J. e Medeiros, A. (1980): A organização do curso de geografia na faculdade de letras de Lisboa depois de 25 de abril de 1974. in Quatro ensaios sobre a geografia em Portugal edited by Arroz, E., Ferrão, E., Gama, A., Gaspar, J., Medeiros, A. e Reis, D., Centro de estudos geográficos, Universidade de Lisboa, 43-56.

Gaspar, J., Honório, F., Honório, J. e Simões, C. (1982): Tansformações recentes na geofrafia do futebol em Portugal. Finisterra, 34, 301-324.

Moreira, M. (1983): Modelado cársico das arribas e plataformas de abrasão-corrosão, no litoral sul de Moçambique. Finisterra, 36, 223-291.

Rebeiro, O. (1945): Portugal: o mediterrâneo e o atlântico. Livraria sá da costa editora.

Rebeiro, O. (1961): Geografia e civilização. Centro de estudos geográficos, Universidade de Lisboa.

Ribeiro, O. (2003): Memórias de um geógrafo. Edições joão sá da costa.

Ribeiro, O., Lautensach, H. e Daveau, S. (1987-1991): Geografia de Portugal. Edições joão sá da costa.

$(2011$ 年 10 月 14 日受付， 2012 年 1 月 10 日受理 $)$ 